\title{
Effect of Oriental Medicinal Plant Extracts on Spore Germination of Alternaria brassicicola and Nature of Inhibitory Substances from Speedweed
}

\author{
Wang-Ching Ho, Department of Biotechnology, Tajen University, Yenpu, Pingtung, Taiwan; Tsung-Yu Wu, De- \\ partment of Plant Protection, National Pingtung University of Science and Technology, Neipu, Pingtung, Taiwan; \\ Huey-Jen Su, Department of Nursing, Meiho Institute of Technology, Neipu, Pingtung, Taiwan; and Wen-Hsiung \\ Ko, Department of Plant Pathology, National Chung Hsing University, Taichung, Taiwan
}

\begin{abstract}
Ho, W. C., Wu, T. Y., Su, H. J., and Ko, W. H. 2007. Effect of oriental medicinal plant extracts on spore germination of Alternaria brassicicola and nature of inhibitory substances from speedweed. Plant Dis. 91:1621-1624.

Among 65 species of oriental medicinal plants tested, 39 contained substances inhibitory to conidial germination of Alternaria brassicicola, with the most inhibitory extract from speedweed (Polygonum perfoliatum). The inhibitory substances in dried speedweed were insoluble in water. However, the inhibitors were readily extracted with ethanol or methanol, but not with acetone, ether, or chloroform. The ethanol extract was very effective in controlling black leaf spot of spoon cabbage, Brassica campestris subsp. chinensis, caused by A. brassicicola. The inhibitory effect of the extract was not affected by treatment with anion exchange resins, but was partially reduced by cation exchange resins, indicating the presence of two inhibitory substances in the extract, one with a positive charge and the other with no charge on its molecule. The inhibitory substances in the extract were dialyzable with molecular weight minimums of 10,000 or 1,000 , but not 500 or 100 , suggesting that both inhibitors have molecular weights between 500 and 1,000 .
\end{abstract}

Additional keyword: iprodione

Leaf spots of crucifers caused by Alternaria brassicicola (Schwein) Wiltshire, $A$. brassicae (Berk.) Sacc., and A. raphani (J.W. Groves \& Skolko) are worldwide in distribution (5). These pathogens have caused considerable losses in cruciferous oil production and vegetable crops yield in different parts of the world $(10,16,18)$. In Taiwan, A. brassicicola, the main causal organism of leaf spot, is widespread on the island, occurring all year round, and causes reduction in quality and yield of cruciferous vegetables.

Control of foliar plant diseases relies heavily upon the use of chemical fungicides $(1,8)$, but high concern for adverse effects of pesticides on human health and the environment requires development of alternative methods for disease control. Extracts from a number of plant species are known to contain substances inhibitory to fungi $(6,19)$, and many essential oils

Corresponding author: W. H. Ko

E-mail: kowh@dragon.nchu.edu.tw

* The $\boldsymbol{e}$-Xtra logo stands for "electronic extra" and indicates that a supplementary table not included in the print edition appears online.

Accepted for publication 18 July 2007.

doi:10.1094/PDIS-91-12-1621

(C) 2007 The American Phytopathological Society show antifungal activity against a wide range of fungi $(7,20)$. The extracts from Reynoutria sachalinensis (F. Schmidt) Nakai (17) and sunflower oil (15) also have been developed for use by growers for control of powdery mildews.

A project was initiated to test the possibility of using extracts of edible plants for control of plant pathogens. Because some Chinese herbs have been used in treating infection by microorganisms $(2,9)$, they were tested for ability to control powdery mildews. Results showed that more than $21 \%$ of dried Chinese herbs purchased from a Chinese herb store contained substances in their aqueous extracts inhibitory to spore germination of Oidium murrayae Hosag., U. Braun \& Rabindram and that extracts from Chinese rhubarb (Rheum officinale Baill.) and Japanese knotweed (Polygonum cuspidatum Sieb \& Zucc.) were very effective in controlling powdery mildews on cucumber, pumpkin, and eggplant (3). A large number of oriental medicinal plants has been collected and planted in recent years in a special nursery at Taitung District Agricultural Improvement Station, Taitung, Taiwan. Extracts were prepared from these plants and tested for inhibition of conidial germination of $A$. brassicicola. The most inhibitory extract from this bioassay was tested for control of black leaf spot and partially characterized.

\section{MATERIALS AND METHODS}

Source of spores. A. brassicicola was isolated from Brassica oleracea L. and identified based on its distinct morphological characteristics of conidia (4). For preparation of conidial suspension, the fungus was grown on $10 \% \mathrm{~V} 8$ agar (10\% V8 juice, $0.02 \% \mathrm{CaCO}_{3}$, and $2 \%$ agar) at $24^{\circ} \mathrm{C}$ in a 12 -h light-and-dark cycle, with cool white fluorescent irradiation. A conidial suspension was prepared by transferring conidial mass from a 2-week-old culture with a transfer loop into $9 \mathrm{ml}$ of sterile distilled water, and the concentration of the suspension was adjusted to approximately $10^{5} \mathrm{spores} / \mathrm{ml}$ by a Pipetman microliter pipet (West Coast Scientific, Oakland, CA; 12).

Preparation of plant extracts. Medicinal plants used in this study were collected from the medicinal plant nursery of Taitung District Agricultural Improvement Station, Taitung, Taiwan. The aboveground parts, including stems, leaves, flowers, and fruit, if they were present at the time of collection, were washed with tap water, air dried, and cut into pieces approximately 5 $\mathrm{cm}$ in length. Extracts were obtained by grinding and pressing these pieces of plant tissues with a juice extractor (Paiyun Co., Taipei, Taiwan) and centrifuged at 6,000 rpm for $15 \mathrm{~min}$, twice. Supernatants were sterilized by filtration through a $0.22-\mu \mathrm{m}$ Millipore filter (Millipore Co., Billerica, MA).

Effects of extracts on spore germination. To test plant extracts for inhibition of spore germination, $10 \mu \mathrm{l}$ of spore suspension of A. brassicicola was mixed with 10 $\mu \mathrm{l}$ of extract in a cavity of a sterile eightcavity slide. Slides with spores were kept moist by placing them on L-shaped glass rods on moistened paper towels in large petri dishes $(150$ by $20 \mathrm{~mm})$ sealed with Parafilm. Germination was recorded after incubation at $24^{\circ} \mathrm{C}$ for $8 \mathrm{~h}$, and 100 spores were counted in each of four replicates. All the experiments were repeated twice. Data presented were means from one of the experiments, with both experiments showing similar results.

Extraction with different solvents and effect on spore germination. Speedweed $(P$. perfoliatum L.) plants were collected at the campus of National Pingtung University of Science and Technology, washed with tap water, dried in an oven at $50^{\circ} \mathrm{C}$ for 
$24 \mathrm{~h}$, and cut into pieces about 1 to $3 \mathrm{~cm}$ in length. Extraction was carried out by shaking $10 \mathrm{~g}$ of tissue with either $100 \mathrm{ml}$ of water, $50 \%$ ethanol, $95 \%$ ethanol, methanol, acetone, ether, or chloroform in a 250 $\mathrm{ml}$ flask on a shaker at 150 strokes/min for $24 \mathrm{~h}$. After filtration, the extract was adjusted to $100 \mathrm{ml}$ with the same solvent. The extract $(5 \mathrm{ml})$ was evaporated to dryness in the fume hood, and the residue was redissolved in $5 \mathrm{ml}$ of $50 \%$ ethanol. The solution was diluted 100-, 250-, 500-, and 1,000 -fold with sterile distilled water before being used for germination tests. Ethanol similarly diluted with distilled water was used as the control. The experiments were performed twice. weed extract. Seeds of spoon cabbage ( $B$. chinensis L. cv. Ching-green) were purchased from Known-You Seed Co., Kaohsiung, Taiwan and grown in 250-ml pots containing a mixture of nine parts peat moss and one part vermiculite. Threeweek-old plants, each with four to five fully expanded leaves, were sprayed to runoff with $50 \%$ ethanol extract of speedweed at 500- and 1,000-fold dilution. For comparison, plants were similarly sprayed with iprodione $(50 \%$, WP), a fungicide inhibitory to A. brassicicola (10) at a 2,000-fold dilution recommended by the manufacturer (Sinon Co., Taichung, Taiwan). Control plants were sprayed with $50 \%$ ethanol diluted 500-fold. After being air dried on the bench, each leaf was inoculated with five $1-\mu \mathrm{l}$ drops of spore sus-
Control of black leaf spot with speed-

pension of $A$. brassicicola along the edge of leaf, and a $15-\mu \mathrm{l}$ drop of $1 \%$ water agar at 60 to $70^{\circ} \mathrm{C}$ was added to each inoculum drop (21). Inoculated plants were placed in moist chambers and kept in the laboratory at $24^{\circ} \mathrm{C}$. The number of lesions that developed at the inoculated sites was recorded 3 days after inoculation. Three leaves per plant were inoculated and three plants were used for each treatment. The experiment was repeated once.

Characterization of inhibitors in speedweed extract and effect on spore germination. To study the effects of different treatments on the inhibitory property of speedweed extract, $10 \mathrm{~g}$ each of Dowex anion exchange resins (Dow Chemical Co., Midland, MI), Lowatit cation exchange resins (Bayer Corporation, Pittsburgh), or activated charcoal (Taipei Chemical Industry Co., Hsinchu, Taiwan) were washed with $100 \mathrm{ml}$ of distilled water three times by shaking for a 6 -h period to remove possible inhibitory substances (13). Then, $50 \mathrm{ml}$ of $50 \%$ ethanol extract of speedweed at 250 -fold dilution was shaken with either $5 \mathrm{~g}$ of each resin or $5 \mathrm{~g}$ of activated charcoal in a 250-ml flask at 150 strokes/min for $24 \mathrm{~h}$ and filtered through a Whatman no. 1 filter paper. The treated extracts were diluted 750-, 1,000-, and 1,250-fold with sterile distilled water before being used for germination tests.

To estimate the molecular weight of the inhibitory substances, $5 \mathrm{ml}$ of $50 \%$ ethanol extract diluted 200-fold was placed in a molecular porous membrane tubing with

Table 1. Effect of extracts of medicinal plants on germination of conidia of Alternaria brassicicola

\begin{tabular}{|c|c|c|c|}
\hline $\begin{array}{l}\text { Plant } \\
\text { no. }\end{array}$ & Scientific name & Common name & $\begin{array}{c}\text { Germination } \\
(\%)^{\mathrm{z}}\end{array}$ \\
\hline 1 & Allium fistulosum & Green onion & 0 \\
\hline 2 & Allium sativum & Garlic & 0 \\
\hline 3 & Allium tuberosum & Chinese chives & 0 \\
\hline 4 & Aster altaicus & & 0 \\
\hline 5 & Averrhoa bilimbi & Cucumber tree & 0 \\
\hline 6 & Belamcanda chinensis & Leopard lily & 0 \\
\hline 7 & Bidens pilosa & Hairy beggarticks & 0 \\
\hline 8 & Bischofia javanica & Autumn maple & 0 \\
\hline 9 & Cedrela sinensis & Chinese cedar & 0 \\
\hline 10 & Chamaesyce hirta & Asthma plant & 0 \\
\hline 11 & Datura stramonium & Jimsonweed & 0 \\
\hline 12 & Derris trifoliata & Asi-asiman & 0 \\
\hline 13 & Euphorbia formosana & Taiwanese euphorbia & 0 \\
\hline 14 & Euphorbia tirucalli & Pencil tree & 0 \\
\hline 15 & Fructus ligustri & Glossy privet fruit & 0 \\
\hline 16 & Garcinia spicata & Common garcinia & 0 \\
\hline 17 & Lygodium japonicum & Climbing fern & 16 \\
\hline 18 & Oxalis corniculata & Yellow wood sorrel & 0 \\
\hline 19 & Phyllanthus urinaria & Shatterstone & 0 \\
\hline 20 & Plumeria rubra & Plumeria & 0 \\
\hline 21 & Pogonatherum crinitum & German grass & 3 \\
\hline 22 & Pogostemon cablin & Patchouli & 0 \\
\hline 23 & Polygonum chinese & Chinese knotweed & 0 \\
\hline 24 & Polygonum cuspidatum & Japanese knotweed & 0 \\
\hline 25 & Polygonum perfoliatum & Speedweed & 0 \\
\hline 26 & Rhinacanthus nasutus & $\ldots$ & 0 \\
\hline 27 & Talinum triangulare & Mikado pheasant & 18 \\
\hline 28 & Water (control) & $\ldots$ & 95 \\
\hline
\end{tabular}

${ }^{\mathrm{y}}$ Spore suspension mixed with the same amount of extract was incubated at $24^{\circ} \mathrm{C}$ for $8 \mathrm{~h}$.

${ }^{\mathrm{z}}$ Four replicates were used for each plant species and 100 spores were counted for each replicate. Percentage of germination was based on the average of two tests. molecular weight minimum of 100,500 , 1,000 or 10,000 , and dialyzed at $24^{\circ} \mathrm{C}$ against $1,500 \mathrm{ml}$ of distilled water changed three times over a $24-\mathrm{h}$ period. The treated extracts were diluted 750-, 1,000-, and 1,250 -fold with sterile distilled water before being used for germination tests.

Four replicates were used for each treatment and all the experiments were repeated twice with similar results. Data presented were means from one of the experiments.

\section{RESULTS}

Effect of extracts obtained from medicinal plants on spore germination. Among the 65 extracts from macerated medicinal plants, 24 contained substances capable of complete inhibition of conidial germination of A. brassicicola (Table 1). Nine extracts reduced the germination rate to 3 to $38 \%$, and six extracts by 60 to $69 \%$. Twenty-six extracts were slightly to noninhibitory to A. brassicicola, with 72 to $94 \%$ germination. When the 24 inhibitory extracts were tested at 50-fold dilution, 6 showed complete inhibition of conidial germination of $A$. brassicicola, whereas 18 other extracts were slightly to noninhibitory to A. brassicicola, with 74 to 94\% germination (Table 2). These six inhibitory extracts then were tested at $100-$, 500-, 1,000-, and 2,000-fold dilutions. Speedweed extract was the most inhibitory to $A$. brassicicola, completely inhibiting germination at 2,000-fold dilution (Table 3 ), and was selected for further studies. Extracts of Japanese knotweed, jimsonweed, and autumn maple were inhibitory to A. brassicicola at 100 -fold dilution but not at 500-fold dilution, while those of Chinese knotweed and Taiwanese euphorbia were not inhibitory at 100 -fold dilution.

Extraction of the inhibitory substances from speedweed. Of the solvents tested, ethanol at $50 \%$ was the most effective in extracting the substances inhibitory

Table 2. Effect of extracts of 24 species of medicinal plants from the first selection on germination of conidia of Alternaria brassicicola at 50-fold dilution

\begin{tabular}{|c|c|}
\hline Source of extract ${ }^{\mathrm{z}}$ & $\begin{array}{c}\text { Germination } \\
(\%)\end{array}$ \\
\hline Speedweed & 0 \\
\hline Autumn maple & 0 \\
\hline Chinese knotweed & 0 \\
\hline Japanese knotweed & 0 \\
\hline Jimsonweed & 0 \\
\hline Taiwanese euphorbia & 0 \\
\hline Water (control) & 94 \\
\hline
\end{tabular}

z Species with extract slightly or non-inhibitory to A. brassicicola: Rhinacanthus nasutus, patchouli, common garcinia, yellow wood sorrel, garlic, hairy beggarticks, cucumber tree, Chinese chives, glossy privet fruit, green onion, asi-asiman, plumeria, asthma plant, pencil tree, leopard lily, Aster altaicus, Chinese cedar, and shatterstone. 
to spore germination of $A$. brassicicola from dried speedweed tissue, followed by methanol and 95\% ethanol (Table 4). Water, acetone, ether, and chloroform were ineffective in extracting the inhibitory substances with the methods used. Subsequently, inhibitory substances obtained by extracting dried speedweed tissue with $50 \%$ ethanol were used for disease control and inhibitor characterization.

Disease control with speedweed extract. Ethanol extract of speedweed was very effective in controlling black leaf spot of spoon cabbage caused by A. brassicicola, reducing the spot incidence from $100 \%$ on the control to $13 \%$ on plants sprayed with extract at 500 -fold dilution (Table 5). Even at 1,000-fold dilution, the extract was able to reduce the leaf spore development to $33 \%$. The fungicide iprodione reduced the spot incidence to $0 \%$.

Nature of inhibitory substances. At 2,500-fold dilution, the speedweed extract completely inhibited the conidial germination of A. brassicicola. The extract was no longer inhibitory to spore germination after treatment with activated charcoal (Table 6). After treatment with cation exchange resins, the extract became noninhibitory at 2,500-fold dilution, but was still strongly inhibitory at the 2,000-fold dilution with only $15 \%$ germination of treated conidia. Repeated treatment with fresh cation exchange resins did not further reduce the inhibitory effect (data not shown). Treatment with anion exchange resins did not affect the inhibitory effect of the extract.

The inhibitory substances in the speedweed extract did not diffuse through the dialysis membrane with molecular weight minimum of 100 or 500 (Table 7). However, the extract in the dialysis tubing with molecular weight minimum of 1,000 or 10,000 was no longer inhibitory to spore germination of $A$. brassicicola following dialysis treatment.

Table 3. Effect of extract dilutions of six medicinal plants on germination of Alternaria brassicicola conidia

\begin{tabular}{lrcc}
\hline & \multicolumn{3}{c}{$\begin{array}{c}\text { Germination (\%) } \\
\text { at } \boldsymbol{n} \text {-fold dilution }\end{array}$} \\
\cline { 2 - 4 } Source of extract $^{\mathbf{z}}$ & $\mathbf{1 0 0}$ & $\mathbf{5 0 0}$ & $\mathbf{1 , 0 0 0}$ \\
\hline Speedweed & 0 & 0 & 0 \\
Japanese knotweed & 0 & 72 & 93 \\
Jimsonweed & 0 & 71 & 92 \\
Autumn maple & 0 & 93 & 93 \\
Chinese knotweed & 95 & 94 & 94 \\
Taiwanese euphorbia & 96 & 97 & 91 \\
Water (control) & 94 & 92 & 94 \\
\hline
\end{tabular}

${ }^{y}$ All plants listed are those that effectively inhibited conidial germination at 50-fold dilution. Data are mean of four replicates from one of the experiments with similar results.

${ }^{\mathrm{z}}$ Spore suspension mixed with the same amount of extract was incubated at $24^{\circ} \mathrm{C}$ for $8 \mathrm{~h}$.

\section{DISCUSSION}

Of the 65 species of oriental medicinal plants tested in this study, $60 \%$ contained substances inhibitory to spore germination of A. brassicicola and nearly $40 \%$ were strongly inhibitory. Although, following dilution, most of the extracts from macerated plants were only moderately or slightly inhibitory, the amount of the fungitoxic substances extracted may be substantially increased when different extraction methods are used (14) or if only

Table 4. Effectiveness of solvents to extract inhibitory substances from speedweed to prevent conidial germination of Alternaria brassicicola ${ }^{\mathrm{y}}$

\begin{tabular}{lcccc}
\hline & \multicolumn{4}{c}{ Germination $(\boldsymbol{\%})$ at $\boldsymbol{n}$-fold dilution } \\
\cline { 2 - 5 } Solvent & $\mathbf{2 0 0}$ & $\mathbf{5 0 0}$ & $\mathbf{1 , 0 0 0}$ & $\mathbf{2 , 0 0 0}$ \\
\hline Water & 89 & 95 & 96 & 95 \\
Ethanol (50\%) & 0 & 0 & 0 & 0 \\
Ethanol (95\%) & 0 & 0 & 87 & 95 \\
Methanol & 0 & 0 & 0 & 97 \\
Acetone & 74 & 96 & 96 & 95 \\
Ether & 98 & 95 & 96 & 96 \\
Chloroform & 97 & 97 & 97 & 97 \\
Control (50\% ethanol) & 99 & nt & nt & nt \\
\hline
\end{tabular}

${ }^{y}$ Leaves, stems, flowers, and fruit of the speedweed plant were used to obtain the extract.

${ }^{\mathrm{z}}$ Spore suspension mixed with the same amount of extract was incubated at $24^{\circ} \mathrm{C}$ for $8 \mathrm{~h}$. Data are mean of four replicates; $\mathrm{nt}=$ not tested.

Table 5. Comparison of speedweed extracts with iprodione for control of black leaf spot of spoon cabbage caused by Alternaria brassicicola

\begin{tabular}{lc}
\hline Treatment & Spot incidence $(\%)^{\mathbf{z}}$ \\
\hline Speedweed extract (500-fold dilution) & $13 \mathrm{~B}$ \\
Speedweed extract (1,000-fold dilution) & $33 \mathrm{C}$ \\
Iprodione & $0 \mathrm{~A}$ \\
Control (50\% ethanol at 500-fold dilution) & $100 \mathrm{D}$ \\
\hline
\end{tabular}

${ }^{\mathrm{z}}$ Each of the three leaves on each plant was inoculated at five locations, and three plants were used for each treatment. Spot development was recorded 3 days after inoculation at $24^{\circ} \mathrm{C}$ with $12 \mathrm{~h}$ of light. Values followed by the same letter are not significantly different by Tukey's significant difference test $(\alpha=0.05)$.

Table 6. Effects of different treatments of speedweed extract on its inhibition of germination of Alternaria brassicicola conidia

\begin{tabular}{|c|c|c|c|c|c|}
\hline \multirow[b]{2}{*}{ Treatment } & \multirow[b]{2}{*}{ pH value ${ }^{z}$} & \multicolumn{4}{|c|}{ Germination $(\%)^{\mathrm{y}}$} \\
\hline & & $\mathbf{0}$ & 1,500 & 2,000 & 2,500 \\
\hline Extract without treatment & 4.6 & $\ldots$ & 0 & 0 & 0 \\
\hline Cation extract resins & 6.9 & $\ldots$ & 0 & 15 & 97 \\
\hline Anion extract resins & 7.2 & $\ldots$ & 0 & 0 & 0 \\
\hline Activated charcoal & 5.9 & $\ldots$ & 97 & 97 & 99 \\
\hline Water (control) & 4.0 & 98 & $\ldots$ & $\ldots$ & $\ldots$ \\
\hline
\end{tabular}

y Percent germination of the spore suspension mixed with the same amount of diluted extract and incubated at $24^{\circ} \mathrm{C}$ for $8 \mathrm{~h}$ at $0-, 1,500-, 2,000-$, and 2,500-fold dilutions.

${ }^{\mathrm{z}} \mathrm{pH}$ value of the extract after treatment.

Table 7. Conidial germination of Alternaria brassicicola in speedweed extracts after treatment with dialysis membranes

\begin{tabular}{lcccc}
\hline & \multicolumn{4}{c}{ Germination $(\%)^{\mathbf{z}}$} \\
\cline { 2 - 5 } Molecular weight minimums & $\mathbf{0}$ & $\mathbf{1 , 5 0 0}$ & $\mathbf{2 , 0 0 0}$ & $\mathbf{2 , 5 0 0}$ \\
\hline 10,000 & $\ldots$ & 96 & 96 & 94 \\
1,000 & $\ldots$ & 97 & 97 & 97 \\
500 & $\ldots$ & 0 & 0 & 0 \\
100 & $\ldots$ & 0 & 0 & 0 \\
Nontreated extract & $\ldots$ & 0 & 0 & 0 \\
Sterilized water & 97 & $\ldots$ & $\ldots$ & $\ldots$
\end{tabular}

${ }^{\mathrm{z}}$ Spore suspension mixed with the same amount of extract was incubated at $24^{\circ} \mathrm{C}$ for $8 \mathrm{~h}$ and percent germination was determined for 0-, 1,500-, 2,000-, and 2,500-fold dilutions. 
weed also contains substances strongly inhibitory to spore germination of A. brassicicola and the substances are very effective in controlling black leaf spot of spoon cabbage cause by this pathogen. The $\mathrm{pH}$ of the extract from speedweed was 4.6. Its inhibitory effect was not due to low $\mathrm{pH}$ because conidial germination of $A$. brassicicola was unaffected by a $\mathrm{pH}$ of water at 4.0. Moreover, after treatment with anion exchange resins, the $\mathrm{pH}$ of the extract became 7.2 and the extract was still inhibitory to spore germination.

Leaves of speedweed turn yellow and fall off in autumn, and the young twigs die during the winter. The plants begin to produce new shoots from old stems in the spring. Therefore, it was necessary to dry stems and leaves for storage and to obtain the extract from dried tissues by extraction with solvent. Results from this study showed that water, acetone, ether, or chloroform was not effective in extracting the inhibitory substances. These inhibitory substances were extracted effectively with ethanol or methanol. The inhibitory effect was not affected by treatment with anion exchange resins. However, part of the inhibitory effect of the extract disappeared and part of it remained unaffected after treatment with cation exchange resins. Results indicate that one inhibitory substance was positively charged and removable by a cation exchange resin but not by the anion resins, whereas another was uncharged and unaffected by cation or anion exchange resins. Molecular weight estimation with membrane suggests that both inhibitors have molecular weights between 500 and 1,000.
Plants tested in this study are used as medicines among oriental people $(2,9)$. Our results show the possibility of using extracts from some of these plants to develop environmentally friendly methods for control of plant diseases.

\section{ACKNOWLEDGMENTS}

This study was supported in part by a grant from the National Science Council of Taiwan (NSC952811-B-055-001). We thank J. H. Huang (Taiwan Agricultural Research Institute, Wufeng, Taichung, Taiwan) for supplying the isolate of A. brassicicola, and S. G. Lee (Taitung District Agricultural Improvement Station, Taitung, Taiwan) for assistance in collecting the oriental medicinal plants used in this study.

\section{LITERATURE CITED}

1. Agrios, G. N. 2005. Plant Pathology, 5th ed. Elsevier Academic Press, San Diego, CA.

2. Bensky, D., and Gamble, A. 1993. Chinese Herbal Medicine: Materia Medica. Eastland Press, Seattle, WA.

3. Chu, Y. L., Ho, W. C., and Ko, W. H. 2006. Effect of Chinese herb extracts on spore germination of Oidium murrayae and nature of inhibitory substance from Chinese rhubarb. Plant Dis. 90:858-861.

4. Ellis, M. B. 1971. Dematiaceous Hyphomycetes. Commonwealth Mycological Institute, Kew, UK.

5. Farr, D. F., Bills, G. F., Chamuris, G. P., and Rossman, A. Y. 1989. Fungi on Plant and Plant Products in the United States. American Phytopathological Society Press, St. Paul, MN.

6. Fawcett, C. H., and Spencer, D. M. 1969. Natural antifungal compounds. Pages 637-669 in: Fungicides, an Advanced Treatise. Volume II, Chemistry and Physiology. D. C. Torgeson, ed. Academic Press, New York.

7. Furita, N., Makoto, M., Kurane, R., and Takahara, Y. 1981. Antifungal activity of components of essential oils. Agric. Biol. Chem. 45:945-952.

8. Hewitt, H. G. 1998. Fungicides in Crop Protection. CAB International, Wallingford,
Oxon, UK.

9. Huang, K. C. 1991. The Pharmacology of Chinese Herbs. CRC Press, Boca Raton, FL.

10. Humpherson-Jones, F. M., and Maudo, R. B. 1982. Control of dark leaf spot (Alternaria brassicicola) of Brassica oleracea seed production crops with foliar sprays of iprodione. Ann. Appl. Biol. 100:99-104.

11. Kan, W. S. 1981. Pharmaceutical Botany. National Research Institute of Chinese Medicine, Taipei, Taiwan.

12. Ko, W. H., Chase, L. L., and Kunimoto, R. K. 1973. A microsyringe method for determining concentration of fungal propagules. Phytopathology 63:1206-1207.

13. Ko, W. H., and Hora, F. K. 1972. Identification of an $\mathrm{Al}$ ion as a soil fungitoxin. Soil Sci. 113:42-45.

14. Ko, W. H., Hora, F. K., and Herlicska, E. 1974. Isolation and identification of a volatile fungistatic substance from alkaline soil. Phytopathology 64:1394-1400.

15. Ko, W. H., Wang, S.Y., Hsieh, T. F., and Ann, P. J. 2003. Effects of sunflower oil on tomato powdery mildew caused by Oidium neolycopersici. J. Phytopathol. 151:144-148.

16. Kolte, S. J., Awasthi, R. P., and Vishwanath, M. 1987. Assessment of yield losses due to Alternaria blight in rape and mustard. Indian Phytopathol. 40:209-211.

17. Konstantinidou-Doltsinis, S., and Schmitt, A. 1998. Impact of treatment with plant extracts from Reynoutria sachalinensis (F. Schmidt) Nakai on intensity of powdery mildew severity and yield in cucumber under high disease pressure. Crop Prot. 17:649-656.

18. McDonald, W. C. 1959. Gray leaf spot of rape in Manitoba. Can. J. Plant Sci. 39:409-416.

19. Sehgal, J. M. 1961. Antimicrobial substances from flowering plants. Hind. Antibiot. Bull. 4:3-29.

20. Singh, A. K., Dickshit, A., Sharma, M. L., and Dixit, S. N. 1980. Fungitoxic activity of some essential oils. Econ. Bot. 34:186-190.

21. Xu, X. L., and Ko, W. H. 1998. A quantitative confined inoculation method for studies of pathogenicity of fungi on plants. Bot. Bull. Acad. Sin. 39:187-190. 